\title{
HALAL SYSTEM IN MEAT INDUSTRIES
}

\section{Sciendo}

Fazly Ann Zainalabidin ${ }^{\mathrm{a}, \mathrm{b}^{*}}$, Fadilah Mohd Hassan ${ }^{\mathrm{a}, \mathrm{c}}$, Nur Sapinah Mat Zinª, Wan Nabilah Wan Azmia and Mohd Iswadi Ismail ${ }^{b}$

aDepartment of Food Science, Faculty of Food Science and Technology, Universiti Putra Malaysia, 43400 UPM Serdang, Selangor, Malaysia

bVeterinary Research Institute, Department of Veterinary Services, 59, Jalan Sultan Azlan Shah, 31400 Ipoh, Perak, Malaysia

cMalaysia Halal Analysis Centre, No. 1, Persiaran Teknologi 1, Lebuh Enstek, 71760 Bandar Baru Enstek, Negeri Sembilan, Malaysia

*Corresponding Author Email: fazly@dvs.gov.my

\section{Doi : 10.2478/mjhr-2019-0001}

\section{ABSTRACT}

Halal certification is one of the prerequisites for entering the global halal market. It does provide recognition of quality and safe product through the concept of halalan toyyiban for the entire supply chain, from farm to fork. In halal meat industry, the system covers from practicing good animal husbandry in the farm until the post-slaughter management in order to maintain the halal status. Animal welfare aspect and ante-mortem inspection were also highlighted in reducing the chances of slaughtering the injured or diseased animal which may not only affecting the meat quality but unhealthy for consumption. Rapid bleeding resulting from the slaughtering process will increases the shelf-life of the meat by reducing the risk of carcass contamination and product deterioration. As the concept of toyyiban (wholesomeness) is practice, the meat is free from any microbiological, physical and chemical hazards.

Keywords: halal, meat, slaughter

\section{INTRODUCTION}

Halal is a Qur'anic term means permissible, allowed and lawful. It is an obligation that should be fulfilled by every Muslims. In relation to food, it carries the meaning "permissible for consumption and utilization by Muslims". As the world's population is projected to grow 35\% in the coming decades, the number of Muslims is expected to increase by 73\% from 1.6 billion in 2010 to 2.8 billion in 2050 [1]. The dominance in Muslim population growth will directly increase the preference for halal food [2]. However, the growing demand for halal food nowadays, is not only for Muslim consumer. In relation to the meat industry, non-Muslim consumer started to purchase halal meat due to food safety concern and the increasing awareness that halal certified food adheres to stringent standard in hygiene and sanitation [3]. In addition, Hafez and others [4] also mentioned that animal that slaughtered by halal means has better meat quality. According to Aziz and Chok [5], halal system could improve the meat industry in term of providing a high quality and safe product and contributes to its marketability. They also reported that halal certification provides a strong recognition of high quality product among the non-Muslim consumers. The certification is also considered to be the prerequisite for entering the global halal market, helping companies to meet the local requirements, and expand the marketplace $[6,7]$.

In order to get the halal certification, the entire supply chain starting from the farm to fork must be halal. Therefore, in producing high quality meat according to halal system, the process started from the source of animals where practicing good husbandry practice, pre-slaughter management, slaughtering process, and post-slaughter management must be taken into consideration. 


\section{GOOD ANIMAL HUSBANDRY PRACTICES}

The production of halal meat according to halal system requires good animal husbandry practices particularly on the animal welfare aspect starting at the farm level. Animal welfare as stated by Krishnan and others [8] are referring to the well-being of animals such as the animal care and humane treatment. Animal welfare is often associated with the quality of the meat. Animal abuse will impose detrimental impacts on meat quality and reduce consumer acceptance as well as devalue the price of meat in the market [9]. The poorly treated animals will result in fatigue, bruising and injury which may lead to bad quality of the raw meat. Injured animals are normally having higher stress levels and tend to develop an increase of glycogen content in the blood from time to time and subsequently cause dark, firm and dry meat $[10,11]$. Poor animal care in the farm will lead to increase the potential animal diseases which reduce the productivity and loss of profit. Islamic teachings encourage good relationship between farm animals and human. On-farm human-animal interactions reduce animals fear and allow ease during handling and thus increase the productivity [12]. Grandin [13] mentioned that implementation of improved handling procedures provides economic benefits such as reduced death losses and bruises. Besides animal handling, according to Shariah law, animals that are to be slaughtered must be fed with good, clean, permitted and legally nutritious food in order to produce good halal meat. Another aspect that needs to be considered in halal system is welfare of the animals during transportation. Good transportation arrangement including humane handling and avoid over-trucking, play a role in reducing animal stress prior to slaughtering that may affect the meat quality [14].

\section{PRE-SLAUGHTER MANAGEMENT}

In halal system, humans are obliged to treat animals in the mindful and attentive way as what has been mentioned in Shariah law. The act of cruelty and animal abuse throughout the halal meat production supply chain is strictly forbidden. This includes the pre-slaughter management upon animal arrival at the slaughterhouse. The animal must be humbly unloaded from the truck, well-rested and has free access to water in the holding pens before being slaughtered. Feed fasting of animals for at least 12 hours before slaughter is important to minimize the migration of gastrointestinal tract bacteria into the meat [15]. However, prolonged withholding of feed with more than 24 hours is not humane $[15,16]$. To ensure the meat from animals intended to be slaughtered are fit consumption, ante-mortem inspection by competent veterinarian is very helpful. Identification of animal for traceability purposes, cleanliness of animals, visible abnormalities as well as indications of animal welfare being compromised, will be detected during the inspection [17]. The signs of infectious or potential zoonotic diseases of the animal also will be observed to ensure that animals are suitable and have the ability to produce safe meat for human consumption.

\section{SLAUGHTERING PROCESS}

Slaughtering is a vital step for meat quality, safety and animal welfare [18]. Halal slaughtering process involves restraining and severing of trachea (halqum), esophagus (mari') and both the carotid arteries and jugular veins (wadajain). At the time of slaughtering, animals must be alive and the slaughter must comply with niyyah, which is the intention of the name of Allah. According to Malaysian Protocol for Halal Meat and Poultry Production by JAKIM [19], the slaughtering knife must be sharp and clean, so the slaughtering process can be done with only once "sawing action". Several studies have shown that, halal slaughtering method that provides considerable bleeding when the heart is still beating and neck incision used in halal cut is beneficial for shelf-life extension and meat quality maintenance. Cut in major blood vessels and used of the sharp knife to perform once cut in halal slaughtering enhanced rapid bleeding resulting in higher amounts of blood loss thereby reducing product deterioration and extend the shelf life of the meat [20]. Poor bleeding in animals and more blood retained after slaughtering will inferior the quality, affecting the appearance and acceptability of the meat [21]. As blood is the perfect medium for bacteria growth, lower amount of residual blood in the carcass subjected to halal slaughter caused lower bacteria count which reduces the risk of carcass contamination, therefore maintain the meat quality by reducing the microbial contamination [22]. Use of sharp knife and science in halal 
slaughtering method can help in maintaining the end quality of the meat product thus can improve the meat industry to produce high quality and safety in meat products [23].

\section{POST-SLAUGHTER MANAGEMENT}

In meat industry, post-slaughter management is one of crucial stages that will determine the quality of meat. At this stage, shelf life and hygienic maintenance of the meat product is very important. In halal system, the toyyiban (wholesomeness) aspect which covers nutritional, quality, cleanliness and safety of the product, would demand the meat to be free from any microbiological, physical and chemical hazards. Thus, after the slaughtering process the meat must be handled and processes in hygienic environment in order to avoid any cross contamination [24]. This is because the cleanliness of the processing area could preserve the meat quality by reducing the risk of meat being contaminated with any microbiological hazard such as Salmonella spp. [25,26]. The meat also should be stored properly at designated area such as cold or chilled room with suitable temperature. Even the transportation storage also needs to be monitored to prevent temperature abuse which can lead to microbial growth. By doing so, the quality of the meat could be maintained with longer shelf life. Therefore, from processing up to transportation, the risk of potential hazard at any level must be eliminated to safeguard the toyyiban aspect of the meat.

\section{CONCLUSION}

Halal system in the production of meat include the good husbandry practice of animal in the farm, animal welfare during pre-slaughter management, slaughtering process and post-slaughter management with halalan toyyiban concept. As a beneficial, the halal meats produced not only fulfill the demands of Muslim consumers but also non-Muslim consumers due to the stringent standard in hygiene and sanitation. Therefore, by practicing halal system, the industry players will be able to obtain the halal certification, which has been considered as the precondition in entering the global halal market.

\section{REFERENCES}

[1] Lipka, M., Hackett, C. 2015. Why muslims are the world's fastest-growing religious group?. Retrieved 6 December 2017 from http://www.pewresearch.org/fact-tank/2015/04/23/why-muslims-are-theworlds-fastest-growing-religious-group/.

[2] Adams, I.A. 2011. Globalization: Explaining the dynamics and challenges of the halal food surge. Intellectual Discourse, 19 (1), 123-145.

[3] Lada, S., Harvey Tanakinjal, G., Amin, H. 2010. Predicting intention to choose halal products using theory of reasoned action. International Journal of Islamic and Middle Eastern Finance and Management, 3 (4), 66-76.

[4] Hafez, O.A., Zaiton, H., Nazmi, A.M.M. 2015. Effect of slaughtering methods on meat quality indicators, chemical changes and microbiological quality of broiler chicken meat during refrigerated storage. IOSR Journal of Agriculture and Veterinary Science, 8 (9), 2319-2372.

[5] Aziz, Y.A., Chok, N.V. 2013. The role of halal awareness, halal certification, and marketing components in determining halal purchase intention among non-muslims in Malaysia: A structural equation modeling approach. Journal of International Food and Agribusiness Marketing, 25 (1), 1-23.

[6] Mathew, V.N., Ardiana, M.R.A.A., Siti Nurazizah, M.I. 2014. Acceptance on halal food among nonmuslim consumers. Procedia-Social and Behavioral Sciences, 121, 262-271.

[7] Noordin, N., Nor Laila, M.N., Samicho, Z. 2014. Strategic approach to halal certification system: an ecosystem perspective. Procedia-Social and Behavioral Sciences, 121, 79-95. 
[8] Krishnan, S., Mohamad-Haniff, M.A., Muhammad-Nabil, A., Muhammad-Nazrin, A.K. 2017. Halal food: study on non-muslim acceptance. American Journal of Economics, 7 (1), 41-45.

[9] Farouk, M.M., Pufpaff, K.M., Amir, M. 2016. Industrial halal meat production and animal welfare: a review. Meat Science, 120, 60-70.

[10] O'Neill, H.A., Webb, E.C., Frylinck, L., Strydom, P.E. 2006. The stress responsiveness of three different breed types and the effect on ultimate $\mathrm{pH}$ and meat colour. In: Proceedings of 52 ${ }^{\text {nd }}$ International Congress of Meat Science and Technology (13-18 August 2006), Dublin, Ireland, 181-182.

[11] Muchenje, V., Dzama, K., Chimonyo, M., Strydom, P.E., Raats, J.G. 2009. Relationship between preslaughter stress responsive and beef quality in three cattle breeds. Meat Science, 81 (4), 653-657.

[12] Ndou, S.P., Muchenje, V., Chimonyo, M. 2011. Assessment and implications of animal welfare in beef production systems in developing countries. African Journal Biotechnology, 10 (7), 1049-1064.

[13] Grandin, T. 2003. Transferring results of behavioral research to industry to improve animal welfare on the farm, ranch and slaughter plant. Applied Animal Behavioral Science, 81 (3), 215-228.

[14] Broom, D.M. 2005. The effects of land transport on animal welfare. Revue Scientifique et Technique, 24 (2), 683-691.

[15] Grandin, T. 2017. Slaughter-dressing of livestock. Retrieved 6 December 2017 from https://meat.tamu.edu/ansc-307-honors/slaughter-livestock/

[16] Ferguson, D.M., Bruce, H.L., Thompson, J.M., Egan, A.F., Perry, D., Shorthose, W.R. 2001. Factors affecting beef palatability - farmgate to chilled carcass. Australian Journal of Experimental Agriculture, 41, 879-891.

[17] Lahti, P., Soini, J. 2014. Ante-mortem inspection. In: T. Ninios, J. Lunden, H. Korkeala and M. Fredriksson-Ahomaa (Eds.), Meat Inspection and Control in the Slaughterhouse, John Wiley \& Sons Ltd., UK, 19-28.

[18] Nakyinsige, K., Fatimah, A., Aghwan, Z., Zulkifli, I., Goh, Y., Sazili, A. 2014. Bleeding efficiency and meat oxidative stability and microbiological quality of New Zealand white rabbits subjected to halal slaughter without stunning and s stun-killing. Asian-Australasian Journal of Animal Sciences, 27 (3), 406-413.

[19] The Department of Islamic Development Malaysia (JAKIM). 2011. Malaysian protocol for the halal meat and poultry productions. Retrieved 24 April 2017 from http://www.halal.gov.my/v4/images/pdf/

[20] Sabow, A.B., Sazili, A.Q., Zulkifli, I., Goh, Y.M., Ab Kadir, M.Z.A., Abdulla, N.R., Nakyinsige, K., Kaka, U., Adeyemi, K.D. 2015. A comparison of bleeding efficiency, microbiological quality and lipid oxidation in goats subjected to conscious halal slaughter and slaughter following minimal anesthesia. Meat Science, $104,78-84$.

[21] Gregory, N.G. 2008. Animal welfare at markets and during transport and slaughter. Meat Science, 80 (1), 2-11.

[22] Ali, S.A.M., Abdalla, H.O., Mahgoub, I.M. 2011. Effect of slaughtering method on the keeping quality of broiler chickens' meat. Egypt Poultry Science, 31 (4), 727-736.

[23] Aghwan, Z.A., Bello, A.U., Abubakar, A.A., Imlan, J.C., Sazili, A.Q. 2016. Efficient halal bleeding, animal handling, and welfare: a holistic approach for meat quality. Meat Science, 121, 420-428. 
[24] Henriques, A.R., Gama, L.T., Fraqueza, M.J. 2017. Tracking Listeria monocytogenes contamination and virulence-associated characteristics in the ready-to-eat meat-based food products industry according to the hygiene level. International Journal of Food Microbiology, 242, 101-106.

[25] Normalina, O.E., Harlina, S.J., Rahimi, O.M. 2013. Halalan toyyiban supply chain of the food industry. Journal of Emerging Economies and Islamic Research, 1 (3), 1-12.

[26] Young, I., Wilhelm, B.J., Cahill, S., Nakagawa, R., Desmarchelier, P., Rajic, A. 2016. A rapid systematic review and meta-analysis of the efficacy of slaughter and processing interventions to control nontyphoidal Salmonella in beef and pork. Journal of Food Protection, 79 (12), 2196-2210. 